\title{
DAMPAK PEMBATASAN IMPOR HORTIKULTURA TERHADAP AKTIVITAS PEREKONOMIAN, TINGKAT HARGA DAN KESEJAHTERAAN
}

\author{
Wisnu Winardi ${ }^{1}$
}

\begin{abstract}
This paper analyzes the impact of entry ports reduction on horticultural production on the economic activities, prices and also toward social welfare by using Computable General Equilibrium (CGE) model. The simulation shows higher import restriction on horticultural products will not only increase the factor income (at current value), but will also increase the composite prices. The higher effect of the latter leads to social welfare reduction, but on the other hand favors the agriculture household types. This finding shows import restriction on horticulture product serves as income redistribution policy instrument. With regard to this, the monetary authority should take the issue into account, especially in order to anticipate the effect of composite prices increase, which could lead to the need of extra efforts in managing price stability.
\end{abstract}

Keywords: import reduction; prices, inflation, CGE; social welfare; income distribution.

JEL Classification: E25, E27

1 Wisnu Winardi is a national accountant at BPS-Statistics Indonesia; wisnuw@bps.go.id, wisnu.winardi@ymail.com. 


\section{PENDAHULUAN}

Pada bulan September 2012 pemerintah menetapkan kebijakan pembatasan pintu masuk untuk produk hortikultura yang mulai berlaku sejak tanggal 28 September 2012. Kebijakan ini merupakan penundaan atas penerapan Peraturan Menteri Perdagangan (Permendag) Nomor 30/M-DAG/PER/5/2012 tentang Ketentuan Impor Produk Hortikultura yang sedianya ditetapkan mulai berlaku 15 Juni 2012. Dengan ketetapan ini pemerintah akan menutup beberapa pelabuhan impor untuk produk hortikultura, sehingga impor hanya boleh masuk ke wilayah pabean Indonesia melalui empat pintu masuk, yaitu Pelabuhan Belawan, Tanjung Perak, Makassar dan Bandara Soekarno-Hatta.

Berdasarkan peraturan ini, akan ada beberapa ketentuan lain mengenai impor hortikultura, terutama yang terkait dengan kesehatan dan lingkungan. Tujuannya adalah melindungi kepentingan konsumen, terutama dalam hal pengendalian masuknya hama penyakit. Selanjutnya kebijakan ini diharapkan akan dapat memberikan manfaat bagi perekonomian nasional, terutama bagi masyarakat umum sebagai konsumen dan petani sebagai produsen.

Kebijakan pembatasan pintu masuk produk hortikultura sering diasosiasikan dengan pembatasan impor hortikultura, sebab implementasi kebijakan ini hampir bisa dipastikan akan mengurangi jumlah impor hortikultura. Dalam perjalanannya, kebijakan ini banyak mendapat respon pro dan kontra dari berbagai pihak. Pihak yang pro menyatakan bahwa kebijakan ini sangat baik untuk dilaksanakan, karena dapat merangsang produsen domestik untuk meningkatkan produksinya. Dengan kebijakan ini pendapatan dan kesejahtaraan petani hortikultura sebagai produsen dalam negeri diharapkan akan meningkat. Namun di sisi lain, kebijakan ini juga mendapat tantangan dari pihak yang kontra baik dari dalam maupun luar negeri. Pihak dari dalam negeri mengkhawatirkan ketersediaan produk hortikultura yang belum sepenuhnya bisa terpenuhi dari dalam negari dan dampak inflasi yang mungkin diakibatkannya. Sedangkan pihak luar negeri atau negara eksportir merasa kebijakan ini merugikan produksi domestiknya dan menganggap peraturan ini melanggar ketentuan tentang perdagangan bebas.

Menurut laporan WTO, Amerika Serikat dengan dukungan negara-negara Uni Eropa, Australia, Chile, Kanada, Selandia Baru dan Afrika Selatan memprotes kebijakan Indonesia menutup beberapa pintu masuk impor produk hortikultura, terutama pelabuhan Tanjung Priok (WTO, 2012). Pemerintah menjelaskan bahwa penutupan beberapa pintu masuk ini disebabkan karena lalu-lintas barang yang sudah sangat padat, serta dukungan sarana dan SDM yang belum memadai dalam menangani masalah perlindungan keamanan pangan. Namun hal ini masih belum bisa diterima negara-negara eksportir sehingga dalam perkembangannya Amerika Serikat telah bereaksi lebih jauh dengan dengan meminta WTO untuk menggugurkan kebijakan pembatasan impor hortikultura Indonesia (ABC, 2013).

Profil produk hortikultura di Indonesia secara umum menunjukan kondisi yang baik. Penyediaan produk hortikultura sebagian besar berasal dari produksi domestik. Berdasarkan 
Neraca Bahan Makanan (NBM), selama periode 2008-2012 peran impor produk hortikultura di Indonesia terhadap total penyediaan berkisar antara 8-12 persen. Impor produk hortikultura yang cukup besar untuk jenis buah-buahan berupa jeruk, apel, anggur, dan durian. Sedangkan untuk jenis sayur-sayuran berupa bawang putih, cabe, bawang merah, dan kentang. Perkembangan peran impor terhadap total penyediaan untuk hampir seluruh produk hortikultura juga menunjukan kecenderungan yang semakin mengecil, kecuali bawang merah dan bawang putih. Peran impor kedua produk tersebut terhadap penyediaan menunjukan kecenderungan yang meningkat.

\begin{tabular}{|c|c|c|c|c|c|c|c|c|c|c|}
\hline \multicolumn{11}{|c|}{$\begin{array}{l}\text { Tabel } 1 \\
\text { Produksi dan Impor Beberapa Produk Hortikultura di Indonesia 2008-2012 (Ribu Ton) }\end{array}$} \\
\hline \multirow{2}{*}{ Komoditas } & \multicolumn{2}{|c|}{2008} & \multicolumn{2}{|c|}{2009} & \multicolumn{2}{|c|}{2010} & \multicolumn{2}{|c|}{$2011^{*}$} & \multicolumn{2}{|c|}{$2012^{\text {** }}$} \\
\hline & Prod. & Imp. & Prod. & Imp. & Prod. & Imp. & Prod. & Imp. & Prod. & $\operatorname{Imp}$ \\
\hline \multicolumn{11}{|l|}{ Buah-buahan } \\
\hline - Jeruk & 2.468 & 139 & 2.132 & 210 & 2.029 & 193 & 1.819 & 218 & 2.139 & 183 \\
\hline - Durian & 682 & 25 & 798 & 29 & 492 & 24 & 884 & 27 & 766 & 17 \\
\hline - Mangga & 2.105 & 1 & 2.243 & 1 & 1.287 & 1 & 2.131 & 1 & 2.351 & 1 \\
\hline - Semangka & 371 & 0 & 474 & 1 & 349 & 1 & 498 & 1 & 419 & 0 \\
\hline - Apel & 161 & 140 & 262 & 154 & 191 & 198 & 200 & 213 & 228 & 132 \\
\hline - Anggur & 22 & 27 & 10 & 37 & 12 & 43 & 12 & 58 & 14 & 44 \\
\hline $\begin{array}{l}\text { - Lainnya } \\
\text { (Melon, Blewah, Stroberi) }\end{array}$ & 242 & 1 & 180 & 1 & 141 & 1 & 208 & 1 & 170 & 1 \\
\hline \multicolumn{11}{|l|}{ Sayur-sayuran } \\
\hline - Bawang Merah & 551 & 83 & 623 & 43 & 677 & 47 & 577 & 104 & 724 & 60 \\
\hline - Kentang & 1.072 & 13 & 1.176 & 19 & 1.061 & 32 & 955 & 93 & 1.128 & 39 \\
\hline - Wortel & 367 & 18 & 358 & 20 & 404 & 34 & 527 & 42 & 427 & 40 \\
\hline - Cabe & 1.153 & 116 & 1.379 & 130 & 1.329 & 131 & 1.483 & 165 & 1.424 & 106 \\
\hline - Buncis & 267 & 6 & 291 & 7 & 336 & 9 & 335 & 9 & 348 & 2 \\
\hline - Bawang Putih & 9 & 304 & 11 & 289 & 9 & 259 & 10 & 300 & 9 & 201 \\
\hline - Jamur & 43 & 2 & 38 & 2 & 61 & 2 & 46 & 2 & 67 & 2 \\
\hline
\end{tabular}

Berdasarkan kondisi tersebut, penelitian ini akan mengkaji apakah kebijakan pembatasan impor untuk produk hortikultura akan menguntungkan perekonomian Indonesia. Penelitian ini mencoba untuk mengkalkulasi bagaimana dampak pembatasan impor produk hortikultura terhadap kesejahteraan masyarakat. Penelitian dilakukan dengan pendekatan simulasi atas penerapan kuota impor dalam model CGE (computable general equilibrium). Selan itu, penelitian ini juga mencoba mengkalkulasi dampak pembatasan impor produk hortikultura terhadap variabel ekonomi lain, seperti harga barang komposit (composite goods), pendapatan faktor riil, dan pendapatan institusi. 


\section{TEORI}

Secara umum, bentuk proteksi terhadap produk domestik atas persaingannya dengan produk impor dapat dilakukan dengan kebijakan tarif dan non-tarif. Kebijakan pembatasan pintu masuk impor produk hortikultura bisa dikategorikan sebagai kebijakan non-tarif (non tariff policy), karena implementasinya diharapkan akan mampu mengurangi komoditas impor yang disasar tanpa menggunakan instrumen tarif². Dampak pembatasan impor atas suatu komoditas terhadap harga komposit di suatu perekonomian dapat dijelaskan dengan Gambar 1. Gambar ini menjelaskan perubahan keseimbangan parsial yang disebabkan bergesernya kurva penyediaan ke sebelah kiri karena impor berkurang. Dalam hal ini kurva permintaan dianggap tetap (Carbaugh, 2008).

Jika penyediaan domestik diwakili garis Sdn, penyediaan dari luar negeri diwakili Sw dan permintaan diwakili Ddn, maka keseimbangan perekonomian tanpa pembatasan impor berada di titik $\mathrm{E}^{0}$. Pada kondisi ini harga yang terwujud adalah $p^{0}$ dan barang yang terjual sebanyak $q^{4}$, dimana sebanyak $q^{0}$ diantaranya berasal dari produk domestik dan sebanyak $q^{4}-q^{0}$ berasal dari impor. Pemberlakuan pembatasan impor akan menggeser keseimbangan menuju ke titik $\mathrm{E}^{1}$. Pada kondisi ini harga yang terwujud menjadi lebih tinggi ( $\left.\mathrm{p} 1\right)$ dan jumlah barang yang terjual menjadi berkurang $\left(q^{3}\right)$, dimana sebanyak $q^{1}$ berasal dari produk domestik dan sebanyak $\left(q^{3}-q^{1}\right)$ berasal dari impor.

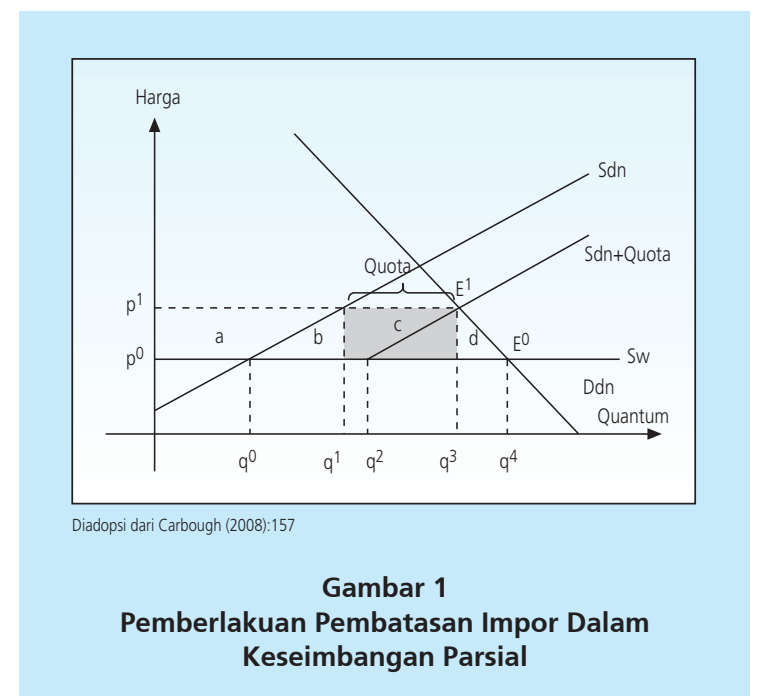

Pembatasan impor akan mengakibatkan harga menjadi lebih tinggi dan jumlah barang yang terjual menjadi lebih sedikit. Pembatasan impor juga akan memunculkan quota rent

2 Secara umum pembatasan impor dapat dilakukan dengan penetapan tarif, subsidi, kuota, larangan impor dan embargo. 
di dalam perekonomian. Quota rent adalah nilai surplus yang berasal dari kenaikan harga barang yang dibayar konsumen dalam negeri karena berlakunya pembatasan impor. Dalam keseimbangan parsial tidak dijelaskan siapa yang menerima manfaat dari quota rent yang wujud, sehingga belum dapat ditentukan dampak yang diterima oleh masing-masing pelaku ekonomi (institusi).

Menurut teori, quota rent dapat didekomposisi menjadi redistribution effect (a), protective effect (b), consumption effect (d), dan revenue effect/quota rent (c). Redistribution effect (a) akan mengakibatkan penerimaan produsen domestik meningkat, protective effect (b) dan consumption effect (d) menjadi bagian yang hilang di dalam perekonomian (deadweight lost), sedangkan revenue effect/quota rent menjadi pendapatan yang akan diterima oleh institusi yang memperoleh manfaat dari pasar yang diproteksi.

\section{METODOLOGI}

Data yang digunakan untuk menurunkan sebagian besar parameter model bersumber dari sistem neraca sosial ekonomi (SNSE) Indonesia tahun 2008 yang disesuaikan. Sedangkan untuk parameter lain berupa constant elasticity of substitution (CES) dan constant elasticity of transformation (CET) mengadopsi parameter yang digunakan dalam penelitian yang dilakukan oleh Teguh (2010). Nilai CES dan CET diasumsikan sebesar 0,5 untuk dua puluh tiga sektor, kecuali sektor industri makanan, minuman dan tembakau diasumsikan sebesar 1,5.

Penyesuaian data SNSE dilakukan untuk memenuhi tujuan analisis dan menyinkronkan dengan persamaan-persamaan yang digunakan dalam model. Penyesuaian tersebut dilakukan dengan merubah format SNSE:

- dari transaksi atas dasar harga pembeli menjadi transaksi atas dasar harga produsen dan menghilangkan blok margin perdagangan dan biaya transportasi;

- menggabungkan blok sektor produksi, komoditi domestik, dan komoditi impor menjadi satu blok sektor;

- menggabungkan sektor konstruksi kedalam sektor industri kimia, pupuk, hasil dari tanah liat, semen, listrik, gas dan air; dan

- mendisagregasi sektor pertanian tanaman pangan menjadi sektor pertanian tanaman pangan tanpa hortikultura dan sektor hortikultura.

Alat analisis yang digunakan adalah model CGE statis yang masuk dalam kategori neoclassical class. Pemilihan model CGE sebagai alat analisis didasari oleh pertimbangan bahwa model ini lebih cocok untuk kasus di negara berkembang dalam menentukan kebijakan ekonomi dibandingkan model-model ekonomi lain seperti persamaan simultan dan model ekonometrik lainnya dalam menganalisis adanya shock makroekonomi (Oktaviani, 2008). Model CGE memberikan framework yang bagus untuk menganalisis masalah yang terkait 
dengan penyesuaian struktural: dampak suatu shock yang bekerja melalui perubahan harga dan insentif pasar dalam mempengaruhi alokasi dan stuktur permintaan, produksi, dan perdagangan (Robinson, 2006). Adapun dipilihnya CGE yang statis adalah karena pertimbangkan ukuran dan kompleksitas model yang lebih bisa tertangani (Hosoe dkk., 2010).

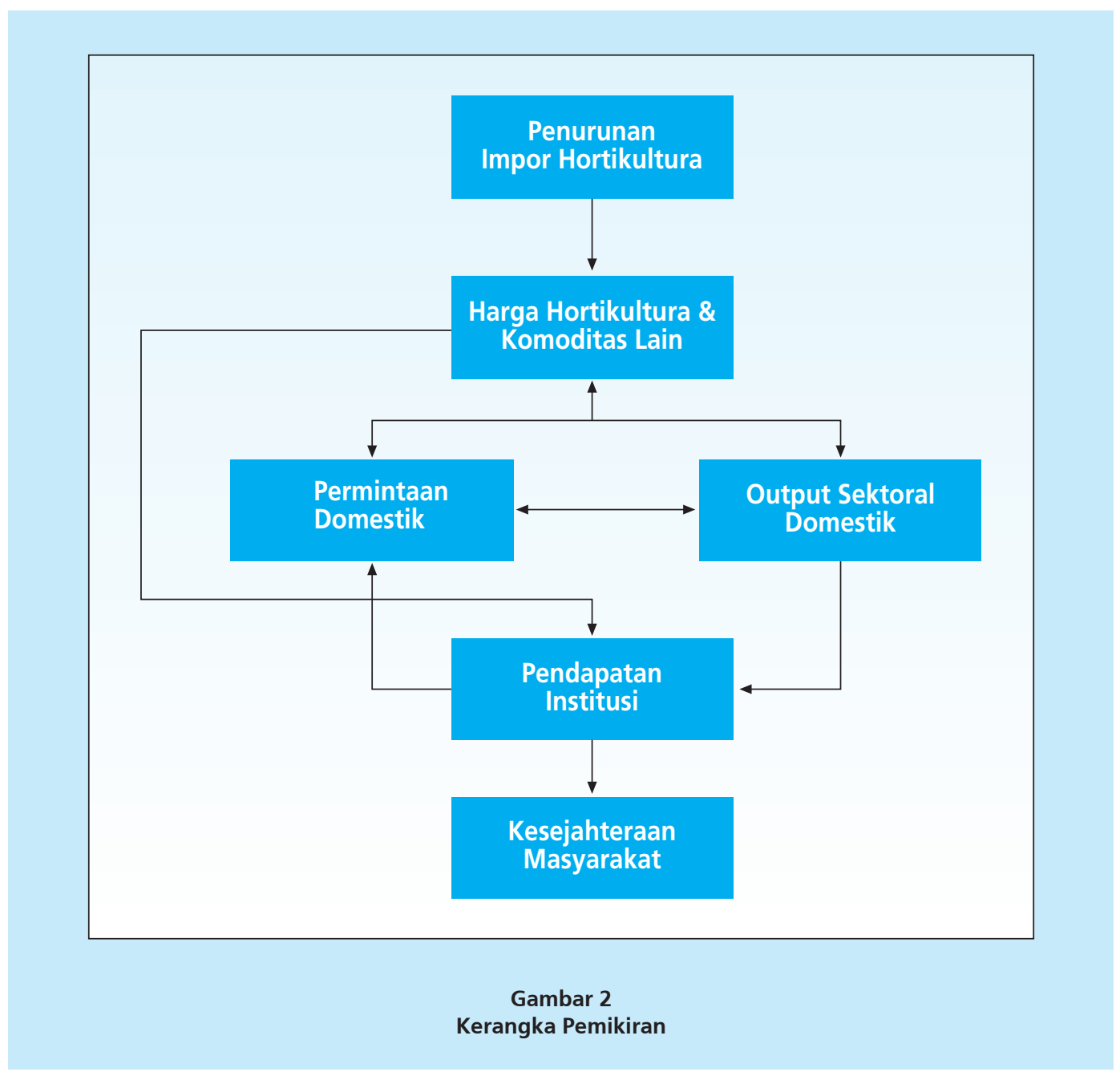

Persamaan yang digunakan sebagian besar diadopsi dari penelitian yang dilakukan oleh Winardi (2012). Kerangka pikirnya diawali dari kebijakan pemerintah dalam mengurangi jumlah pintu masuk impor produk hortikultura yang disertai dengan ketentuan lain yang terkait lingkungan dan kesehatan akan mengakibatkan penurunan impor produk hortikultura. Seperti diperlihatkan dalam Gambar 2, penurunan impor mengakibatkan berkurangnya penyediaan di dalam negeri sehingga berdampak pada naiknya harga komposit produk hortikultura dan 
komiditas lain. Kenaikan harga akan berdampak pada permintaan domestik dan output sektoral. Perubahan output sektoral akan berdampak pada pendapatan yang diterima oleh pelaku ekonomi (institusi) dan selanjutnya akan berdampak pada permintaan domestik dan kesejahteraan masyarakat. Di sisi lain, kenaikan harga juga berpengaruh pada pendapatan riil institusi. Pembatasan impor menjadi sebuah guncangan (shock) dalam perekonomian dan akan berdampak pada seluruh aspek dalam perekonomian, termasuk diantaranya kesejahteraan masyarakat.

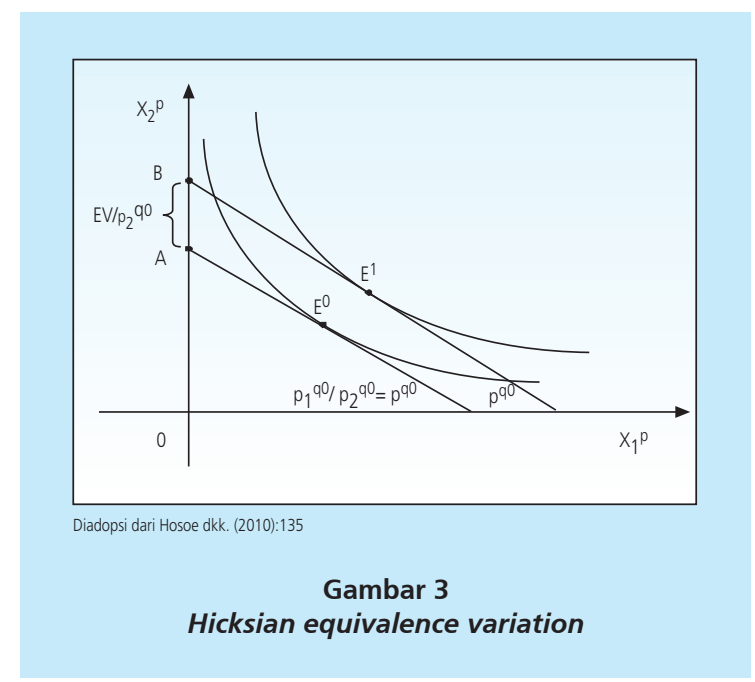

Indikator perubahan kesejahteraan masyarakat dihitung berdasarkan selisih nilai koefisien Hicksian equivalence variation (EV). Nilai EV mengukur perubahan nilai utilitas karena pengaruh pendapatan, tanpa memperhatikan adanya perubahan harga. Nilai EV merupakan transformasi dari nilai utilitas rumah tangga yang diukur dalam skala ordinal menjadi nilai pengeluaran yang diukur dalam satuan moneter (monetary unit). Nilai utilitas rumah tangga itu sendiri merupakan fungsi tujuan (objective function) dari model CGE yang digunakan. Penghitungan nilai pengeluaran dan koefisien EV menggunakan formula berikut (Hosoe dkk., 2012):

$$
\begin{aligned}
& \operatorname{ep}\left(p^{q}, U U\right)=\min _{X^{p}}\left\{p^{q} \cdot X^{p} \mid U U\left(X^{p}\right)=U U\right\} \\
& \text { ep(.) : : fungsi pengeluaran } \\
& X^{p} \quad \text { : vektor konsumsi } \\
& p^{q} \quad \text { : vektor harga yang dihadapi konsumen } \\
& \text { UU : nilai utilitas (given) } \\
& \text { UU(.) : : fungsi utilitas }
\end{aligned}
$$


Fungsi pengeluaran meminimumkan kombinasi konsumsi dan harga untuk menghasilkan nilai utilitas.

$$
E V=e p\left(p^{q 0}, U U^{1}\right)-e p\left(p^{q 0}, U U^{0}\right)
$$

$$
\begin{array}{ll}
\text { EV } & : \text { Hicksian equivalence variation } \\
p^{q 0} & : \text { vektor harga pada kondisi base line } \\
U U^{1} & : \text { nilai utilitas dengan adanya shock } \\
U U^{0} & : \text { nilai utilitas pada kondisi base line }
\end{array}
$$

EV dihasilkan dari selisih pengeluaran rumah tangga yang dihasilkan pada kondisi dengan shock dan pengeluaran tanpa shock (base line) dengan mempertahankan harga pada kondisi base line. Ilustrasi secara grafis tentang koefisien EV untuk dua komoditas $\left(X_{1}\right.$ dan $\left.X_{2}\right)$ adalah seperti pada Gambar 3, dimana nilai EV/p ${ }_{2}{ }^{\circ}$ digambarkan sebesar jarak antara titik A dan B.

Selanjutnya untuk mengukur distribusi pendapatan digunakan indeks Williamson yang memiliki nilai antara 0 hingga 1. Semakin indeks mendekati 0 menunjukan ketimpangan distribusi pendapatan rumah tangga yang rendah, sedangkan semakin mendekati 1 menunjukan ketimpangan yang tinggi. Penghitungan indeks Williamson menggunakan formula berikut (Daryanto, 2010; dimodifikasi):

$$
W=\frac{\sqrt{\sum\left(y_{i}-\bar{y}\right)^{2} f_{i} / n}}{\bar{y}}
$$

W: indeks Williamson

$f_{i}:$ jumlah penduduk golongan rumah tangga ke-i

$n$ : jumlah penduduk total

$y_{i}$ : pendapatan golongan rumah tangga ke-i

$\Sigma$ : pendapatan rumah tangga per kapita

Dampak pembatasan impor hortikultura terhadap distribusi pendapatan rumah tangga dilihat dari perbandingan indeks Williamson yang dihasilkan. Bila indeks dengan kebijakan lebih rendah dari indeks pada kondisi base line maka dapat disimpulkan bahwa kebijakan tersebut akan mengurangi kesenjangan. Demikian sebaliknya, bila indeks dengan kebijakan lebih tinggi dari pada kondisi base line maka dapat disimpulkan bahwa kebijakan tersebut akan meningkatkan kesenjangan. 


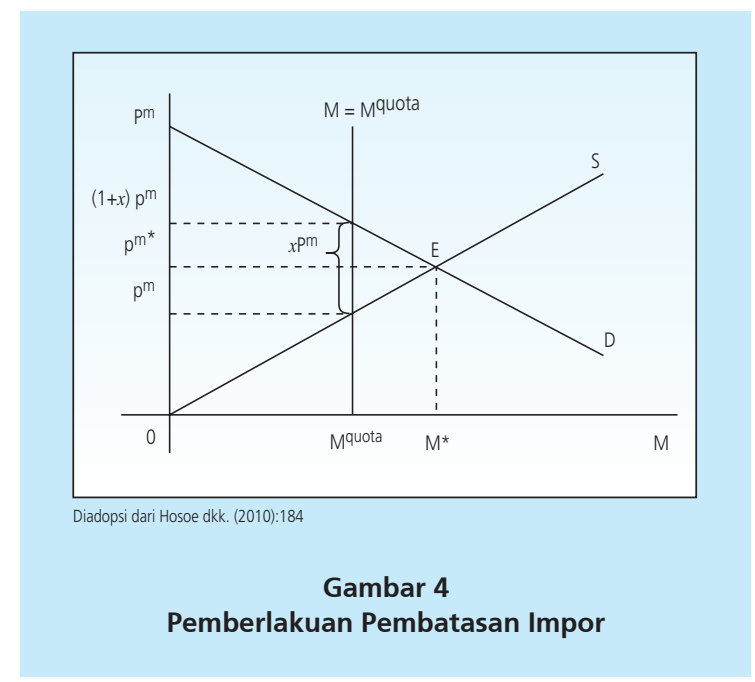

Agar model dapat menggambarkan realita ekonomi yang terjadi dan mampu menjawab tujuan penelitian, maka perlu dilakukan: penyesuaian terhadap sebagian dari persamaan yang diadopsi, penambahan persamaan baru, dan penambahan beberapa variabel dan parameter baru. Ketiga hal ini ditentukan dengan mempertimbangkan bagaimana kebijakan pembatasan impor dituangkan dalam model. Pembatasan impor hortikultura dalam model dapat dijelaskan dalam Gambar 4.

Jika dimisalkan bahwa pada kondisi keseimbangan awal harga barang impor adalah $p^{m *}$ dan jumlah impor adalah $M^{*}$, maka pemberlakuan pembatasan impor akan mengurangi jumlah impor hortikultura menjadi sebesar $M^{q u o t a}$. Pada kondisi ini harga impor hortikultura naik menjadi $(1+\chi) p^{m}$, dan quota rent yang tercipta adalah sebesar $M^{\text {quota }} \cdot(1+\chi) p^{m}$. Sebagaimana Gambar 1, Gambar 4 juga menjelaskan pemberlakuan pembatasan impor dalam keseimbangan parsial, sehingga belum dijelaskan institusi yang mendapatkan manfaat dari kebijakan pengurangan impor. Dalam model keseimbangan umum seperti yang digunakan dalam penelitian ini quota rent diasumsikan akan diterima oleh rumah tangga pertanian (buruh pertanian dan pengusaha pertanian) sebagai institusi yang menghasilkan produk hortikultura di pasar yang diproteksi.

Berdasarkan penjelasan tersebut, persamaan yang disesuaikan, persamaan baru yang ditambahkan, dan variabel dan parameter baru adalah:

- Persamaan yang sesuaikan dalam model adalah:

$$
M_{i}=\left[\frac{\gamma_{i}^{\eta_{i}} \cdot \delta m_{i} \cdot p_{i}^{q}}{\left(1+\chi_{i}+\tau_{i}^{m}\right) p_{i}^{m}}\right]^{\frac{1}{1-\eta_{i}}} \operatorname{Arm}_{i}
$$




$$
\begin{aligned}
& T_{r}^{d}=\tau_{r}^{d}\left(\sum_{h} p_{h}^{f} \cdot F F_{h r}+\operatorname{trhhr}(r)+\operatorname{trhohest}(r)+\operatorname{trhohgov}(r) \quad \forall r\right. \\
& \left.+\varepsilon \cdot \operatorname{trhohext}(r)+\operatorname{rrt}_{r} \sum_{i} R T_{i}\right) \\
& S_{r}^{p}=s s_{r}^{p}\left(\sum_{h} p_{h}^{f} \cdot F F_{h r}+\operatorname{trhhr}(r)+\operatorname{trhohest}(r)+\operatorname{trhohgov}(r)\right. \\
& \left.+\varepsilon \cdot \operatorname{trhohext}(r)+r r t_{r} \cdot \sum_{i} R T_{i}\right) \\
& X_{i r}^{p}=\frac{\alpha_{i r}}{p_{i}^{q}}\left(\sum_{h} p_{h}^{f} \cdot F F_{h r}+\operatorname{trhh} r(r)+\operatorname{trhohest}(r)+\operatorname{trhohgov}(r)\right. \\
& +\varepsilon . \operatorname{trhohext}(r)+r r t_{r} \sum_{i} R T_{i}-T_{r}^{d}-S_{r}^{p} \\
& -\operatorname{trhhc}(r)-\operatorname{tresthoh}(r))
\end{aligned}
$$

$M_{i} \quad$ : impor barang ke-i

$\operatorname{Arm}_{i} \quad$ : barang komposit (kombinasi barang domestik dan impor) ke-i

$\gamma_{i} \quad$ : scaling coeficient pada barang komposit ke-i

$\eta \quad$ : parameter yang ditentukan oleh fungsi koefisien CES

$\tau_{i}^{m} \quad$ : rasiopajak impor terhadap impor barang ke-i

$p_{i}^{m} \quad$ : harga impor

$\delta m_{i} \quad$ : input share pada fungsi barang komposit Armington $(0 \leq \delta \mathrm{mi} \leq 1)$

$T_{r}^{d} \quad$ : pajak langsung rumah tangga ke-r

$\tau^{d} \quad$ : rasio pajak langsung terhadap pendapatan rumah tangga ke-r

$p_{h}^{f} \quad:$ harga faktor ke-h

$\mathrm{FF}_{h r} \quad$ : endowment factor ke-h yang dimiliki rumah tangga ke-r

trhhr : penerimaan tansfer antar rumah tangga

trhohest : penerimaan tansfer rumah tangga dari perusahaan

trhohgov : penerimaan tansfer rumah tangga dari pemerintah 


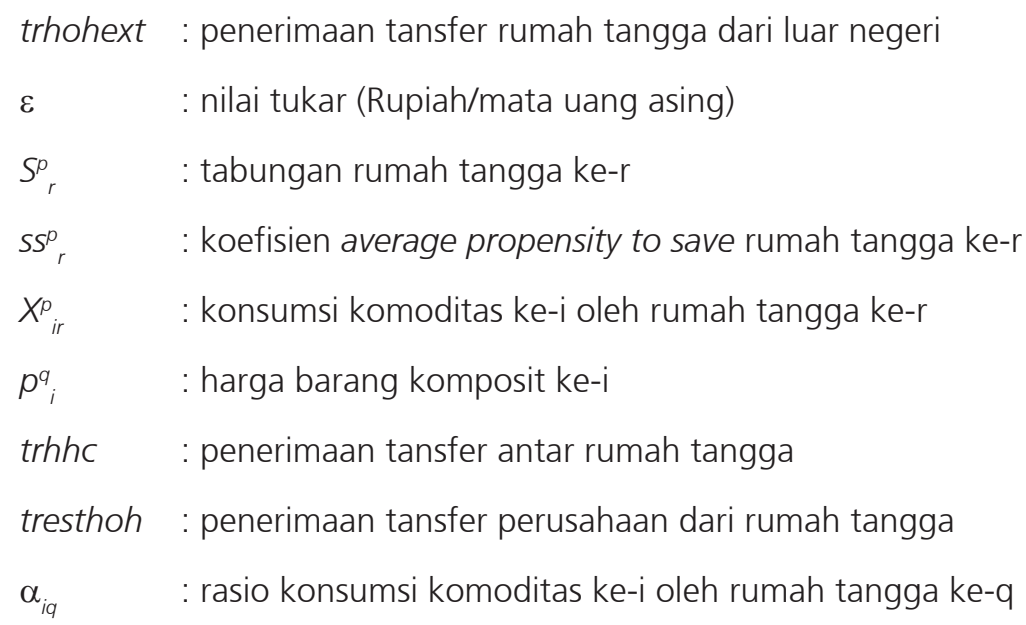

- Persamaan baru yang ditambahkan adalah:

$$
\begin{array}{lc}
R T_{i}=\chi_{i} \cdot p_{i}^{m} \cdot M_{i} & \forall i \\
\chi_{i} .\left(M_{i}^{q u o t a}-M_{i}\right)=0 & \forall i \\
M_{i}^{q u o t a}-M_{i} \geq 0 & \forall i
\end{array}
$$

- Variabel baru yang ditambahkan adalah:

$$
\begin{array}{ll}
\chi_{i} & : \text { quota rent } \\
R T_{i} & : \text { surplus yang disebabkan oleh penerapan kuota impor }
\end{array}
$$

- Parameter baru yang ditambahkan adalah:

$$
\begin{array}{ll}
M_{i}^{\text {quota }} & : \text { kuota impor } \\
r t_{r} & : \text { share penerimaan quota rent oleh rumah tangga ke-r }
\end{array}
$$

Parameter share penerimaan quota rent oleh rumah tangga buruh pertanian dan pengusaha pertanian dihitung berdasarkan perbandingan penerimaan pendapatan faktor rumah tangga buruh pertanian dan pengusaha pertanian pada kondisi base line terhadap total keduanya.

Model ini menggunakan savings-driven closure, yaitu nilai tabungan ditentukan terlebih dahulu baru kemudian investasi setiap sektor menyesuaikan dengan besarnya tabungan. Model termasuk dalam kategori neoclassical class, dengan fungsi produksi diasumsikan bersifat constant return to scale, dan pasar berada pada kondisi persaingan sempurna. Model bekerja dengan prinsip optimasi yang memaksimumkan nilai tujuan, yaitu jumlah utilitas setiap golongan rumah tangga. Pemilihan total utilitas sebagai variabel yang akan dimaksimumkan didasarkan pada 
pertimbangan bahwa kebijakan yang diambil dalam perekonomian memiliki tujuan untuk meningkatkan kesejahteraan. Nilai total utilitas dianggap sebagai indikator yang representatif untuk mewakili karakteristik kesejahteraan.

Untuk membantu komputasi model digunakan GAMS, software untuk menyelesaikan model-model matematika, termasuk CGE. Sedangkan solver yang digunakan adalah conopt, sebuah solver yang lazim digunakan untuk menyelesaikan fungsi optimasi pemrograman non linear (non linear programing, NLP). Simulasi yang dilakukan adalah mengkalkulasi dampak apabila pembatasan pintu masuk impor akan mengurangi jumlah impor hortikultura sebesar 5, 10 dan 20 persen.

Sebelum melakukan analisis hasil simulasi, model CGE yang digunakan perlu diuji terlebih dahulu untuk memastikan bahwa hasil simulasinya tepat dan konsisten. Karena model CGE termasuk dalam kelompok model yang deterministik, maka tidak ada pengujian statistik yang dilakukan terhadap parameter model sebagaimana dilakukan dalam model-model yang bersifat stokastik. Pengujian yang dilakukan dalam model CGE adalah berupa uji sensitifitas terhadap parameter yang berpotensi memberikan pengaruh yang besar terhadap hasil penghitungan. Dalam kasus yang terkait dengan perdagangan internasional seperti yang dilakukan ini, uji sensitifitas dapat dilakukan terhadap parameter CES dan CET yang digunakan (Hosoe dkk., 2010).

Hasil uji sensitifitas terhadap parameter CES dan CET menujukan bahwa model CGE yang digunakan memberikan hasil simulasi dampak pengurangan impor hortikultura sebesar 5, 10, dan 15 persen terhadap nilai EV tiap golongan rumah tangga yang tepat dan konsisten. Hasil pengujian menunjukan bahwa apabila parameter CES dan CET masing-masing komoditas berubah sebesar empat puluh persen lebih rendah atau lebih tinggi dibandingkan dengan nilai pada kondisi base line, hasil simulasi akan tetap tepat dan konsisten. Hal ini ditunjukan dengan nilai EV yang konsisten baik dilihat dari tanda (positif/negatif) maupun dari urutan nilai EV menurut golongan rumah tangga pada kondisi nilai CES dan CET yang berubah (Lampiran 1).

\section{HASIL DAN ANALISIS}

Berikut akan diuraikan hasil simulasi penurunan impor hortikultura sebesar 5, 10 dan 20 persen terhadap beberapa variabel ekonomi, yaitu: harga barang komposit, pendapatan faktor riil, pendapatan institusi, dan kesejahteraan masyarakat.

\section{Dampak Terhadap Harga Barang Komposit}

Pengurangan impor hortikultura sebesar 5 persen diperkirakan akan berdampak pada kenaikan rata-rata harga komposit sebesar 0,01 persen. Kenaikan harga komposit lebih 
disebabkan karena kenaikan harga komposit komoditas sektor hortikultura yang naik sebesar 0,6 persen, sementara harga komoditas sektor lain tetap. Besarnya dampak pengurangan impor hortikultura terhadap harga komposit di setiap sektor adalah seperti disajikan pada Tabel 2.

Seperti dijelaskan dalam Gambar 1, pengurangan impor akan menurunkan penyediaan barang di pasar sehingga akan meningkatkan harga komposit dan membuat barang yang terjual menjadi berkurang. Perubahan harga yang terlokalisir hanya pada sektor hortikultura menujukan bahwa produk hortikultura tidak memiliki keterkaitan kedepan (forward linkage) yang besar. Output hortikultura tidak banyak digunakan sebagai input (bahan baku atau penolong) oleh sektor-sektor lain untuk berproduksi, sehingga kenaikan harga yang terjadi tidak berpengaruh terhadap harga output.

Pengurangan impor hortikultura sebesar 10 dan 20 persen terhadap perubahan harga komposit diperkirakan akan berdampak pada perubahan harga yang lebih tinggi dan semakin menyebar ke sektor-sektor yang lain. Sektor-sektor yang sebelumnya tidak terkena dampak menjadi turut bereaksi bila pengurangan impor menjadi semakin besar. Hasil simulasi menunjukan bahwa dengan pengurangan impor hortikultura sebesar 10 persen akan berdampak pada kenaikan rata-rata harga sebesar 0,02 persen dan terdapat tiga sektor yang mengalami kenaikan harga, sedangkan dengan pengurangan 20 persen akan berdampak pada kenaikan rata-rata harga sebesar 0,08 persen dan terdapat tujuh sektor yang mengalami kenaikan harga. Dampak kenaikan harga yang semakin menyebar mengakibatkan peran (share) sektor hortikultura terhadap perubahan rata-rata harga menjadi menurun, sedangkan sektor-sektor lain meningkat. Peran sektor hortikultura turun dari 100,0 persen pada pengurangan impor sebesar 5 persen menjadi 80,7 persen dan 55,7 persen pada pengurangan impor sebesar 10 dan 20 persen.

Hasil ini juga menunjukan bahwa kebijakan pembatasan impor hortikultura juga akan berdampak pada indikator kebijakan moneter. Sifat barang yang saling komplementer dan subsitusi serta mekanisme demand-supply yang terjadi dalam pasar mengakibatkan perubahan harga yang semakin menyebar. Dalam konteks dekomposisi inflasi, kenaikan harga komoditas yang semakin menyebar berarti bahwa kebijakan pembatasan impor akan mempengaruhi perubahan harga pada komoditas yang dipantau dalam penghitungan inflasi, baik yang bersifat volatile, administered, maupun core. 


\section{Tabel 2}

Dampak Pembatasan Impor Hortikultura Terhadap Perubahan Harga Barang Komposit (Persen)

\begin{tabular}{|c|c|c|c|c|c|c|}
\hline \multirow{2}{*}{ Sektor } & \multicolumn{6}{|c|}{ Pengurangan Impor } \\
\hline & $5 \%$ & Share & $10 \%$ & Share & $20 \%$ & Share \\
\hline 1. Pertanian tanaman pangan selain hortikultura & - & & - & & - & \\
\hline 2. Pertanian hortikultura & 0,6 & 100,0 & 1,3 & 80,7 & 3,0 & 55,7 \\
\hline 3. Pertanian tanaman pangan lainnya & - & & - & & - & \\
\hline 4. Pertanian tanaman lainnya & - & & - & & - & \\
\hline 5. Peternakan dan hasil-hasilnya & - & & - & & 0,1 & 3,9 \\
\hline 6. Kehutanan dan herburuan & - & & - & & - & \\
\hline 7. Perikanan & - & & - & & - & \\
\hline 8. Pertambangan batu bara, biji logam \& minyak bumi & - & & - & & - & \\
\hline 9. Pertambangan dan penggalian lainnya & - & & - & & - & \\
\hline 10. Industri makanan, minuman dan tembakau & - & & - & & 0,1 & 12,4 \\
\hline 11. Industri pemintalan, tekstil, pakaian \& kulit & - & & - & & 0,1 & 3,1 \\
\hline 12. Industri kayu \& barang dari kayu & - & & - & & - & \\
\hline $\begin{array}{l}\text { 13. Industri kertas, percetakan, alat angkutan dan barang dari } \\
\text { logam dan industri }\end{array}$ & - & & - & & - & \\
\hline $\begin{array}{l}\text { 14. Industri kilang minyak, kimia, pupuk, hasil dari tanah liat, } \\
\text { semen, LGA, dan konstruksi }\end{array}$ & - & & - & & - & \\
\hline 15. Perdagangan \& restoran & - & & - & & 0,1 & 13,4 \\
\hline 16. Perhotelan & - & & 0,1 & 1,3 & 0,2 & 0,8 \\
\hline 17. Angkutan kereta api & - & & - & & - & \\
\hline 18. Angkutan darat & - & & - & & - & \\
\hline 19. Angkutan udara, air dan komunikasi & - & & - & & - & \\
\hline 20. Jasa penunjang angkutan, dan pergudangan & - & & - & & - & \\
\hline 21. Bank dan asuransi & - & & - & & - & \\
\hline 22. Real estate dan jasa perusahaan & - & & - & & - & \\
\hline 23. Pemerintahan & - & & 0,1 & 18,0 & 0,2 & 10,7 \\
\hline 24. Jasa perseorangan, ruta dan lainnya & - & & - & & - & \\
\hline Total & 0,01 & 100,0 & 0,02 & 100,0 & 0,08 & 100,0 \\
\hline
\end{tabular}

Harga komposit hortikultura maupun total keseluruhan sektor relatif bersifat inelastis terhadap penurunan impor hortikultura. Persentase kenaikan harga komposit lebih rendah dibandingkan dengan penurunan impor hortikultura. Hal ini disebabkan karena peran impor hortikultura terhadap penyediaan dan forward linkage hortikultura yang tidak besar dan penggunaannya tidak menyebar ke banyak sektor. Sektor yang paling terkena dampak adalah hortikultura itu sendiri diikuti sektor lain yang menginput hortikultura sebagai bahan baku atau penolong untuk proses produksinya dalam jumlah yang cukup besar. 


\section{Dampak Terhadap Pendapatan Faktor Riil}

Pengurangan impor hortikultura sebesar 5, 10 dan 20 persen diperkirakan akan berdampak negatif terhadap total pendapatan faktor riil dan besarnya berbeda untuk setiap sektor. Semakin besar pengurangan impor hortikultura akan mengakibatkan penurunan pendapatan faktor riil yang lebih besar. Besarnya dampak pengurangan impor hortikultura terhadap pendapatan faktor riil menurut sektor adalah seperti disajikan pada Tabel 3.

\begin{tabular}{|c|c|c|c|}
\hline \multicolumn{4}{|c|}{$\begin{array}{c}\text { Tabel } 3 \\
\text { Dampak Pembatasan Impor Hortikultura Terhadap Pendapatan Faktor Riil (Persen) }\end{array}$} \\
\hline \multirow{2}{*}{ Sektor } & \multicolumn{3}{|c|}{ Pengurangan Impor } \\
\hline & $5 \%$ & $10 \%$ & $20 \%$ \\
\hline 1. Pertanian tanaman pangan selain hortikultura & 0,010 & 0,020 & 0,043 \\
\hline \multirow{2}{*}{$\begin{array}{l}\text { 2. Pertanian hortikultura } \\
\text { Pertanian hortikultura* }\end{array}$} & $-0,032$ & $-0,070$ & $-0,163$ \\
\hline & 1,124 & 2,314 & 4,947 \\
\hline 3. Pertanian tanaman pangan lainnya & 0,000 & 0,000 & 0,001 \\
\hline 4. Pertanian tanaman lainnya & 0,001 & 0,001 & 0,004 \\
\hline 5. Peternakan dan hasil-hasilnya & 0,006 & 0,013 & 0,025 \\
\hline 6. Kehutanan dan herburuan & 0,005 & 0,011 & 0,024 \\
\hline 7. Perikanan & 0,013 & 0,027 & 0,057 \\
\hline 8. Pertambangan batu bara, biji logam \& minyak bumi & $-0,006$ & $-0,011$ & $-0,018$ \\
\hline 9. Pertambangan dan penggalian lainnya & 0,002 & 0,004 & 0,009 \\
\hline 10. Industri makanan, minuman dan tembakau & $-0,002$ & $-0,004$ & $-0,009$ \\
\hline 11. Industri pemintalan, tekstil, pakaian \& kulit & $-0,003$ & $-0,006$ & $-0,005$ \\
\hline 12. Industri kayu \& barang dari kayu & 0,002 & 0,005 & 0,013 \\
\hline 13. Industri kertas, percetakan, alat angkutan dan barang dari logam dan industri & 0,001 & 0,003 & 0,009 \\
\hline 14. Industri kilang minyak, kimia, pupuk, hasil dari tanah liat, semen, LGA, dan konstruksi & 0,002 & 0,005 & 0,012 \\
\hline 15. Perdagangan \& restoran & 0,000 & 0,001 & 0,001 \\
\hline 16. Perhotelan & $-0,067$ & $-0,140$ & $-0,306$ \\
\hline 17. Angkutan kereta api & 0,011 & 0,022 & 0,048 \\
\hline 18. Angkutan darat & 0,008 & 0,017 & 0,037 \\
\hline 19. Angkutan udara, air dan komunikasi & 0,008 & 0,016 & 0,034 \\
\hline 20. Jasa penunjang angkutan, dan pergudangan & 0,003 & 0,006 & 0,015 \\
\hline 21. Bank dan asuransi & 0,005 & 0,010 & 0,021 \\
\hline 22. Real estate dan jasa perusahaan & 0,004 & 0,009 & 0,018 \\
\hline 23. Pemerintahan & $-0,024$ & $-0,051$ & $-0,118$ \\
\hline 24. Jasa perseorangan, ruta dan lainnya & 0,008 & 0,017 & 0,037 \\
\hline Total & $-0,0002$ & $-0,0004$ & $-0,0006$ \\
\hline Tot a I* & 0,017 & 0,035 & 0,076 \\
\hline * Pendapatan faktor + quota rent & & & \\
\hline
\end{tabular}


Pengurangan impor hortikultura akan menyebabkan penyediaannya menjadi berkurang. Berkurangnya ketersediaan akan mengakibatkan pemenuhan kebutuhan hortikultura sebagai intermediate input oleh sektor produksi juga menjadi berkurang sehingga berdampak pada penurunan output produksi di beberapa sektor. Hal ini selanjutnya mengakibatkan pendapatan faktor di beberapa sektor juga menjadi turun. Di sisi yang lain, pengurangan impor hortikultura yang berdampak pada kenaikan harga komposit juga akan menekan permintaan. Tekanan terhadap permintaan akan membuat produksi menjadi turun yang juga akan membuat pendapatan faktor menjadi turun. Hasil simulasi menunjukan bahwa pengurangan impor hortikultura sebesar 5, 10 dan 20 persen akan mengakibatkan penurunan total pendapatan faktor riil masing-masing sebesar 0,0002 persen, 0,0004 persen, dan 0,0006 persen, dimana penurunan ini lebih disebabkan oleh penurunan yang terjadi di enam sektor.

Turunnya pendapatan faktor akibat pengurangan impor masih terkompensasi oleh munculnya quota rent yang dihasilkan oleh sektor hortikultura. Apabila quota rent dijumlahkan dengan pendapatan faktor, maka pengurangan impor hortikutura diperkirakan akan berdampak pada peningkatan pendapatan faktor. Hasil simulasi menunjukan bahwa semakin besar penuruan impor hortikultura akan memunculkan quota rent yang semakin besar. Pengurangan impor hortikultura sebesar 5, 10 dan 20 persen akan mengakibatkan peningkatan pendapatan faktor masing-masing sebesar 0,017 persen, 0,035 persen, dan 0,076 persen.

\section{Dampak Terhadap Pendapatan Institusi}

Pengurangan impor hortikultura sebesar 5, 10, dan 20 persen diperkirakan akan berdampak pada naiknya pendapatan institusi (at current values). Seluruh institusi mengalami kenaikan pendapatan, dimana kenaikan yang tinggi dialami oleh rumah tangga pengusaha pertanian dan buruh pertanian. Besarnya dampak pengurangan impor hortikultura terhadap pendapatan institusi adalah seperti disajikan pada Tabel 4.

\begin{tabular}{|c|c|c|c|}
\hline \multicolumn{4}{|c|}{$\begin{array}{c}\text { Tabel } 4 \\
\text { Dampak Pembatasan Impor Hortikultura Terhadap Pendapatan Institusi, (Persen, kecuali bertanda }{ }^{\wedge} \text { ) }\end{array}$} \\
\hline Institusi & $\begin{array}{l}\text { Pengurangan } \\
\text { Impor 5\% }\end{array}$ & $\begin{array}{l}\text { Pengurangan } \\
\text { Impor } 10 \%\end{array}$ & $\begin{array}{l}\text { Pengurangan } \\
\text { Impor } 20 \%\end{array}$ \\
\hline 1. Rumah tangga buruh pertanian & 0,077 & 0,159 & 0,343 \\
\hline 2. Rumah tangga pengusaha pertanian & 0,104 & 0,216 & 0,463 \\
\hline 3. Rumah tangga gol bawah di perdesaan & $2,12 \mathrm{E}-04$ & $6,76 \mathrm{E}-04$ & 0,003 \\
\hline 4. Rumah tangga bkn angkatan kerja di perdesaan & $2,61 \mathrm{E}-04$ & $7,88 \mathrm{E}-04$ & 0,003 \\
\hline 5. Rumah tangga gol atas di perdesaan & 7,89E-04 & 0,002 & 0,005 \\
\hline 6. Rumah tangga gol bawah di perkotaan & 3,33E-04 & $8,66 \mathrm{E}-04$ & 0,003 \\
\hline 7. Rumah tangga bkn angkatan kerja di perkotaan & $5,62 \mathrm{E}-04$ & 0,001 & 0,004 \\
\hline 8. Rumah tangga gol atas di perkotaan & 6,64E-04 & 0,002 & 0,004 \\
\hline
\end{tabular}




\section{Tabel 4}

Dampak Pembatasan Impor Hortikultura Terhadap Pendapatan Institusi, (Persen, kecuali bertanda ${ }^{\wedge}$ )

\begin{tabular}{l|c|c|c}
\multicolumn{1}{c|}{ Institusi } & $\begin{array}{c}\text { Pengurangan } \\
\text { Impor 5\% }\end{array}$ & $\begin{array}{c}\text { Pengurangan } \\
\text { Impor 10\% }\end{array}$ & $\begin{array}{c}\text { Pengurangan } \\
\text { Impor 20\% }\end{array}$ \\
\hline Total rumah tangga & 0,003 & 0,007 & 0,017 \\
\hline 9. Perusahaan & 0,003 & 0,007 & 0,017 \\
\hline 10. Pemerintah & $5,10 \mathrm{E}-04$ & 0,002 & 0,009 \\
\hline Selisih indeks Wiliamson rumah tangga^ & $-0,00028$ & $-0,00058$ & $-0,00125$ \\
* Pendapatan faktor + quota rent & & &
\end{tabular}

Pengurangan impor hortikultura sebesar 5, 10, dan 20 persen berdampak pada kenaikan pendapatannya institusi dengan urutan yang sama. Pada pengurangan impor hortikultura sebesar 5 persen, urutan institusi yang paling tinggi kenaikan pendapatannya adalah rumah tangga dan perusahaan (0,003 persen) dan pemerintah (0,0005 persen). Golongan rumah tangga yang mengalami kenaikan pendapatan tinggi adalah pengusaha pertanian $(0,104$ persen) dan buruh pertanian (0,077 persen). Keuntungan yang diperoleh rumah tangga pertanian dari penerapan kebijakan ini berasal dari quota rent. Kenaikan harga barang akibat berkurangnya penyediaan hortikultura mengakibatkan pendapatan yang diterima petani sebagai produsen hortikultura meningkat.

Besarnya quota rent yang diperoleh petani akan tergantung pada seberapa besar faktor endowment yang dimiliki. Rumah tangga pengusaha pertanian memiliki faktor endowment yang lebih besar dibandingkan dengan buruh pertanian sehingga quota rent yang diperoleh rumah tangga pengusaha pertanian lebih besar dibandingkan dengan rumah tangga buruh pertanian. Hasil simulasi menunjukan bahwa pengurangan impor hortikultura sebesar 5, 10 dan 20 persen akan mengakibatkan peningkatan pendapatan rumah tangga pengusaha pertanian meningkat masing-masing sebesar 0,104 persen, 0,216 persen, dan 0,463 persen. Sedangkan pendapatan rumah tangga buruh pertanian akan meningkat sebesar masing-masing 0,077 persen, 0,159 persen, 0,343 persen. Selain golongan rumah tangga pengusaha pertanian dan buruh pertanian, kenaikan pendapatan yang diterima institusi adalah lebih rendah dibandingkan dengan kenaikan harga komposit (lihat Tabel 1 dan Tabel 4).

Selanjutnya dengan menggunakan indeks Williamson diketahui bahwa pada penurunan impor hortikultura sebesar 5 persen, nilai indeks menurun sebesar 0,00028 dibandingkan indeks pada kondisi base line. Sedangkan pada penurunan sebesar 10 dan 20 persen, nilai indeks masing-masing turun sebesar 0,00058 dan 0,00125. Meskipun penurunan indeks tersebut tidak terlalu besar namun hal ini mengindikasikan bahwa pengurangan impor hortikultura yang makin besar akan berdampak pada penurunan kesenjangan distribusi pendapatan rumah tangga yang juga semakin besar. 
Dalam konteks ini, kebijakan pengurangan impor hortikultura di satu sisi sesuai untuk dilaksanakan bila dikaitkan dengan perkembangan kondisi distribusi pendapatan di Indonesia yang akhir-akhir ini cenderung semakin senjang. Berdasarkan indikator gini rasio, kesenjangan di Indonesia cenderung semakin meningkat, dari 0,31 pada tahun 1999, menjadi 0,37 pada tahun 2009, dan secara terus menerus meningkat hingga menjadi 0,41 pada tahun 2012 (BPS, 2013). Kebijakan ini diharapkan akan membantu penurunan kesenjangan melalui peningkatan pendapatan rumah tangga pertanian yang selama ini mendominasi jumlah rumah tangga miskin di Indonesia.

\section{Dampak Terhadap Kesejahteraan Masyarakat}

Pengurangan impor hortikultura sebesar 5, 10 dan 20 persen diperkirakan akan berdampak pada penurunan kesejahteraan masyarakat secara umum. Enam golongan rumah tangga mengalami penurunan nilai EV, sedangkan dua golongan rumah tangga yaitu buruh pertanian dan pengusaha mengalami kenaikan. Besarnya dampak pengurangan impor hortikultura terhadap kesejahteraan masyarakat tangga adalah seperti disajikan pada Tabel 5.

Dampak penurunan impor terhadap kesejahteraan masyarakat menurut urutannya menujukan hasil yang sejalan dengan dampak terhadap pendapatan institusi. Kenaikan nilai EV yang tinggi diterima oleh golongan rumah tangga pengusaha pertanian dan buruh pertanian, sedangkan golongan rumah tangga yang lain mengalami penurunan, dimana penurunan tertinggi dialami oleh rumah tangga bukan pertanian golongan bawah di perkotaan. Pada pengurangan impor sebesar 5 persen, rumah tangga pengusaha pertanian meningkat sebesar 336 milyar Rupiah dan buruh pertanian meningkat sebesar 93 milyar Rupiah, sedangkan rumah tangga bukan pertanian golongan bawah di perkotaan turun sebesar 204 milyar Rupiah.

\begin{tabular}{|c|c|c|c|c|c|c|}
\hline \multicolumn{7}{|c|}{$\begin{array}{l}\text { Tabel } 5 \text { Dampak Pembatasan Impor Hortikultura Terhadap } \\
\text { Nilai Equivalen of Variation (EV) Rumah Tangga, (Miliar Rp, \%) }\end{array}$} \\
\hline \multirow{2}{*}{ Golongan Rumah Tangga } & \multicolumn{2}{|c|}{$\begin{array}{l}\text { Pengurangan } \\
\text { Impor } 5 \%\end{array}$} & \multicolumn{2}{|c|}{$\begin{array}{l}\text { Pengurangan } \\
\text { Impor } 10 \%\end{array}$} & \multicolumn{2}{|c|}{$\begin{array}{l}\text { Pengurangan } \\
\text { Impor } 20 \%\end{array}$} \\
\hline & EV & $\%$ & EV & $\%$ & EV & $\%$ \\
\hline 1. Buruh pertanian & 93 & 0,06 & 191 & 0,12 & 402 & 0,25 \\
\hline 2. Pengusaha pertanian & 336 & 0,05 & 674 & 0,10 & 1.365 & 0,21 \\
\hline 3. Golonganbawah di perdesaan & -78 & $-0,02$ & -165 & $-0,04$ & -371 & $-0,08$ \\
\hline 4. Bukan angkatan kerja di perdesaan & -25 & $-0,02$ & -52 & $-0,03$ & -117 & $-0,07$ \\
\hline 5. Golongan atas di perdesaan & -54 & $-0,01$ & -114 & $-0,03$ & -257 & $-0,07$ \\
\hline 6. Golongan bawah di perkotaan & -204 & $-0,03$ & -431 & $-0,07$ & -971 & $-0,15$ \\
\hline 7. Bukan angkatan kerja di perkotaan & -51 & $-0,02$ & -109 & $-0,05$ & -245 & $-0,11$ \\
\hline 8. Golongan atas di perkotaan & -72 & $-0,01$ & -153 & $-0,02$ & -348 & $-0,05$ \\
\hline Total & -55 & $-0,002$ & -158 & $-0,005$ & -543 & $-0,016$ \\
\hline
\end{tabular}


Pada pengurangan impor sebesar 10 persen dan 20 persen, simulasi menunjukan hasil dengan struktur yang sama. Perbedaan hanya terletak pada besaran dampak yang ditimbulkan. Semakin besar pengurangan impor hortikultura akan semakin meningkatkan nilai EV rumah tangga pertanian dan semakin menurunkan nilai EV golongan rumah tangga yang lain.

Pada pengurangan impor sebesar 5 persen, rumah tangga buruh pertanian meningkat sebesar 0,06 persen dan pengusaha pertanian meningkat sebesar 0,05 persen, sedangkan rumah tangga bukan pertanian golongan bawah di perkotaan turun sebesar 0,03 persen. Secara relatif rumah tangga yang mengalami kenaikan tinggi adalah buruh pertanian dan pengusaha pertanian, sedangkan penurunan tertinggi masih dialami oleh rumah tangga bukan pertanian golongan bawah di perkotaan. Meskipun secara nominal pengusaha pertanian meningkat lebih tinggi dibandingkan buruh pertanian, namun tidak demikian bila dilihat secara relatif. Hal ini disebabkan oleh nilai konsumsi rumah tangga pengusaha pertanian pada kondisi base line yang jauh labih tinggi dibandingkan buruh pertanian.

\section{KESIMPULAN}

Berdasarkan hasil penelitian, tujuan kebijakan pemerintah untuk melindungi konsumen dengan menerapkan kuota impor hortikultura memiliki trade off dalam berbagai aspek. Pengurangan impor hortikultura sebesar 5 persen, 10 persen dan 20 persen diperkirakan akan memberikan hasil yang berbeda secara besaran namun tidak terlalu berbeda secara struktur. Hasil simulasi menunjukan bahwa semakin besar pengurangan impor hortikultura berdampak pada:

- kenaikan harga komposit yang semakin tinggi dan menyebar luas ke sektor-sektor yang lain;

- $\quad$ penurunan pendapatan faktor yang lebih dalam;

- kenaikan pendapatan faktor (at current values), namun kenaikannya lebih rendah dibandingkan kenaikan harga komposit;

- $\quad$ penurunan kesenjangan distribusi pendapatan rumah tangga; dan

- penurunan kesejahteraan masyarakat secara umum, namun meningkatkan kesejahteraan rumah tangga pertanian.

Berdasarkan hasil tersebut kebijakan pembatasan impor hortikultura bisa disebut sebagai kebijakan yang berorientasi pada pemerataan (pro equality) dan bukan pada pertumbuhan (pro growth). Pemeratan yang wujud bukan disebabkan kenaikan produktifitas, namun lebih disebabkan oleh naiknya penerimaan rumah tangga pertanian dari quota rent produk hortikultura.

Bagi otoritas moneter, tekanan harga barang komposit akibat kebijakan pembatasan impor perlu untuk mendapatkan perhatian. Tekanan harga membawa konsekwensi tentang perlunya usaha yang lebih keras untuk mengantisipasi dampak terhadap stabilitas harga dan moneter yang diakibatkannya. 


\section{DAFTAR PUSTAKA}

ABC (Radio Australia). "AS minta WTO gugurkan pembatasan impor Indonesia", www. radioaustralia.net.au/indonesian/2013-03-15/as-minta-wto-gugurkan-pembatasan-imporindonesia/1102254, diakses 21-4-2013 pukul 04.51WIB.

Badan Ketahanan Pangan dan BPS. 2012. "Neraca Bahan Makanan Indonesia 2010-2011". Jakarta.

2011. "Neraca Bahan Makanan Indonesia 2009-2010".

Jakarta.

2010. "Neraca Bahan Makanan Indonesia 2008-2009".

Jakarta.

BPS. 2013. "Indikator Konsumsi Terpilih, Indonesia 1999, 202-2012", www.bps.go.id/tab_sub/ view.php?kat=1\&tabel=1\&daftar=1\&id_subyek=05\&notab=8, diakses 10-5-2013 pukul 14.58WIB.

Carbaugh, RJ. 2008. "International Economics, 13th Edition". Mason. South-Western Cengage Learning.

Daryanto, A. dan Yundy H. (2010). "Model-model Kuantitatif Untuk Pembangunan Ekonomi Daerah: Konsep dan Aplikasi". IPB Press.

Hosoe, Nobuhiro, Kenji Gasawa and Hideo Hashimoto. 2010. "Textbook of Computable General Equilibrium: Programing and Simulations". Great Britain. Palgrave Macmillan.

Oktaviani, Rina. 2008. "Model Teori Ekonomi Keseimbangan Umum: Teori dan Aplikasinya di Indonesia". Bogor. Departemen Ilmu Ekonomi Fakultas Ekonomi IPB.

Robinson, Sherman. (2006). "Macro Models and Multipliers: Leontief, Stone, Keynes, and CGE Models". Poverty, Inequlity and Development, Essays in Honor of Eric Thorbecke, Chapter 11. Economic Studies in Inequality, Social Exclusion and Well-Being Volume 1, 2006, pp 205-232.

Teguh, Dartanto. 2010. "Volatility of World Rice Prices, Import Tariffs and Poverty in Indonesia: a CGE-Microsilulation Analysis", MPRA Paper No. 31451. Diunduh dari http://mpra.ub.unimuenchen.de/31451/1/MPRA_paper_31451.pdf pada tanggal 7 Februari 2012.

Winardi, Wisnu. 2012. "Simulasi Dampak Penghapusan Tarif Impor Sektor Industri Tekstil Terhadap Penerimaan dan Pengeluaran Institusi Pemerintah Dengan Model Computable General Equilibrium (CGE)". Tesis Program Magister Ilmu Ekonomi Universitas Trisakti. 


\section{LAMPIRAN}

\begin{tabular}{|c|c|c|c|c|c|c|c|c|c|c|}
\hline \multirow{3}{*}{ No } & \multicolumn{10}{|c|}{$\begin{array}{l}\text { Lampiran } 1 \\
\text { Uji sensitifitas: Dampak Pengurangan Impor 5, 10, dan } 15 \text { Persen } \\
\text { Terhadap Nilai EV Golongan Rumah Tangga }\end{array}$} \\
\hline & \multirow{2}{*}{ Golongan Rumah Tangga } & \multicolumn{3}{|c|}{ Pengurangan Impor $\mathbf{5 \%}$} & \multicolumn{3}{|c|}{ Pengurangan Impor $10 \%$} & \multicolumn{3}{|c|}{ Pengurangan Impor $15 \%$} \\
\hline & & $\begin{array}{c}40 \% \text { lebih } \\
\text { rendah }\end{array}$ & Base line & $\begin{array}{c}40 \% \text { lebih } \\
\text { tinggi }\end{array}$ & $\begin{array}{c}40 \% \text { lebih } \\
\text { rendah }\end{array}$ & Base line & $\begin{array}{c}40 \% \text { lebih } \\
\text { tinggi }\end{array}$ & $\begin{array}{c}40 \% \text { lebih } \\
\text { rendah }\end{array}$ & Base line & $\begin{array}{l}40 \% \text { lebih } \\
\text { tinggi }\end{array}$ \\
\hline 1 & 6. Golongan bawah di perkotaan & $-343,39$ & $-203,82$ & $-143,08$ & $-748,75$ & $-430,69$ & $-297,83$ & $-1.812,51$ & $-971,48$ & $-649,55$ \\
\hline 2 & 3. Golongan bawah di perdesaan & $-132,20$ & $-78,32$ & $-54,89$ & $-287,40$ & $-165,14$ & $-114,05$ & $-692,52$ & $-370,98$ & $-247,88$ \\
\hline 3 & 8. Golongan atas di perkotaan & $-128,33$ & $-71,92$ & $-47,50$ & $-281,24$ & $-152,66$ & $-99,33$ & $-688,89$ & $-347,80$ & $-218,72$ \\
\hline 4 & 5. Golongan atas di perdesaan & $-91,84$ & $-53,76$ & $-37,22$ & $-200,58$ & $-113,75$ & $-77,56$ & $-487,72$ & $-257,34$ & $-169,58$ \\
\hline 5 & 7. Bukan angkatan kerja di perkotaan & $-87,05$ & $-51,43$ & $-35,95$ & $-189,90$ & $-108,73$ & $-74,85$ & $-460,29$ & $-245,46$ & $-163,35$ \\
\hline 6 & 4. Bukan angkatan kerja di perdesaan & $-41,66$ & $-24,74$ & $-17,38$ & $-90,54$ & $-52,14$ & $-36,09$ & $-218,08$ & $-117,06$ & $-78,39$ \\
\hline 7 & 1. Buruh pertanian & 154,43 & 93,18 & 66,50 & 327,27 & 190,72 & 133,86 & 748,27 & 402,42 & 271,75 \\
\hline 8 & 2. Pengusaha pertanian & 549,01 & 335,55 & 242,58 & $1.142,63$ & 674,25 & 479,47 & $2.514,41$ & $1.364,65$ & 933,09 \\
\hline
\end{tabular}

